

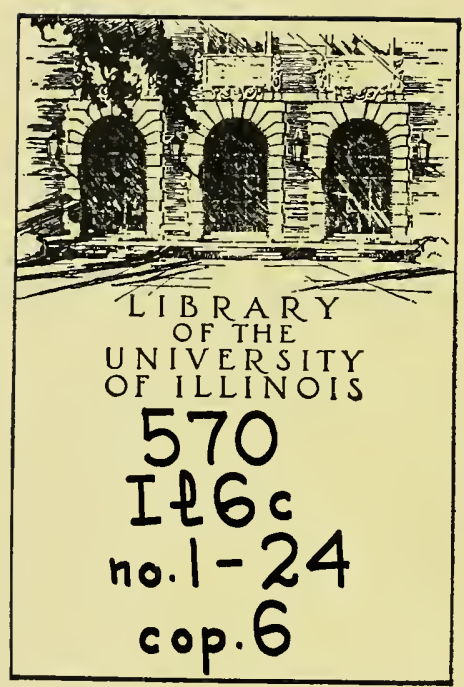

NATURAL HISTORY
SURVEY 

Digitized by the Internet Archive in 2011 with funding from University of Illinois Urbana-Champaign 
STATE OF ILLINOIS

DEPARTMENT OF REGISTRATION AND EDUCATION

DIVISION OF THE

NATURAL HISTORY SURVEY

FORESTRY CIRCULAR NO. 4

\title{
Wood as a Crop in Illinois
}

\author{
BY \\ C. J. TELFORD, Forester \\ Illinois State Natural History Survey
}

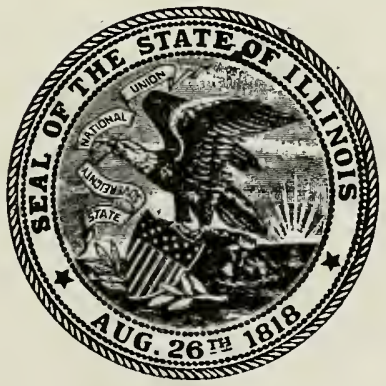

PRINTED BY AUTHORITY OF THE STATE OF ILLINOIS

URBANA, ILLINOIS

June, 1926

\section{U. OF ILL LIE.}




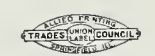

Schnepp \& Barnes, Printers

SPRINGFIELd, IlL.

1926

$51133-5 \mathrm{M}$ 


\section{NOTE}

The Illinois State Natural History Survey has made, during the last five years, a forest survey of the state, employing for the purpose from one to five trained foresters, and has thus obtained dependable information on the location and area of wooded tracts, the amounts, kinds, and values of their content, the kinds of trees present and their rates of growth, and the relation of wood supplies, local and imported, to the industries of the state. The published reports of this investigation are in themselves too voluminous, complex, and full of statistical detail for general use as an introduction to the subject, and the following brief circular has been prepared to bring some of the more important results of the survey to the attention of the people of the state and especially to its farmers, who own 93 per cent of the woodlands of Illinois and the greater part of the waste lands which might be profitably planted to forest trees as a crop. The problem of wood-lot management and utilization will be discussed at length in a practical treatise now in course of preparation, but in the meantime certain typical facts and general ideas concerning the past, present, and possible future of forestry in Illinois deserve to become more widely known.

Stephen A. Forbes,

Chief of Survey. 


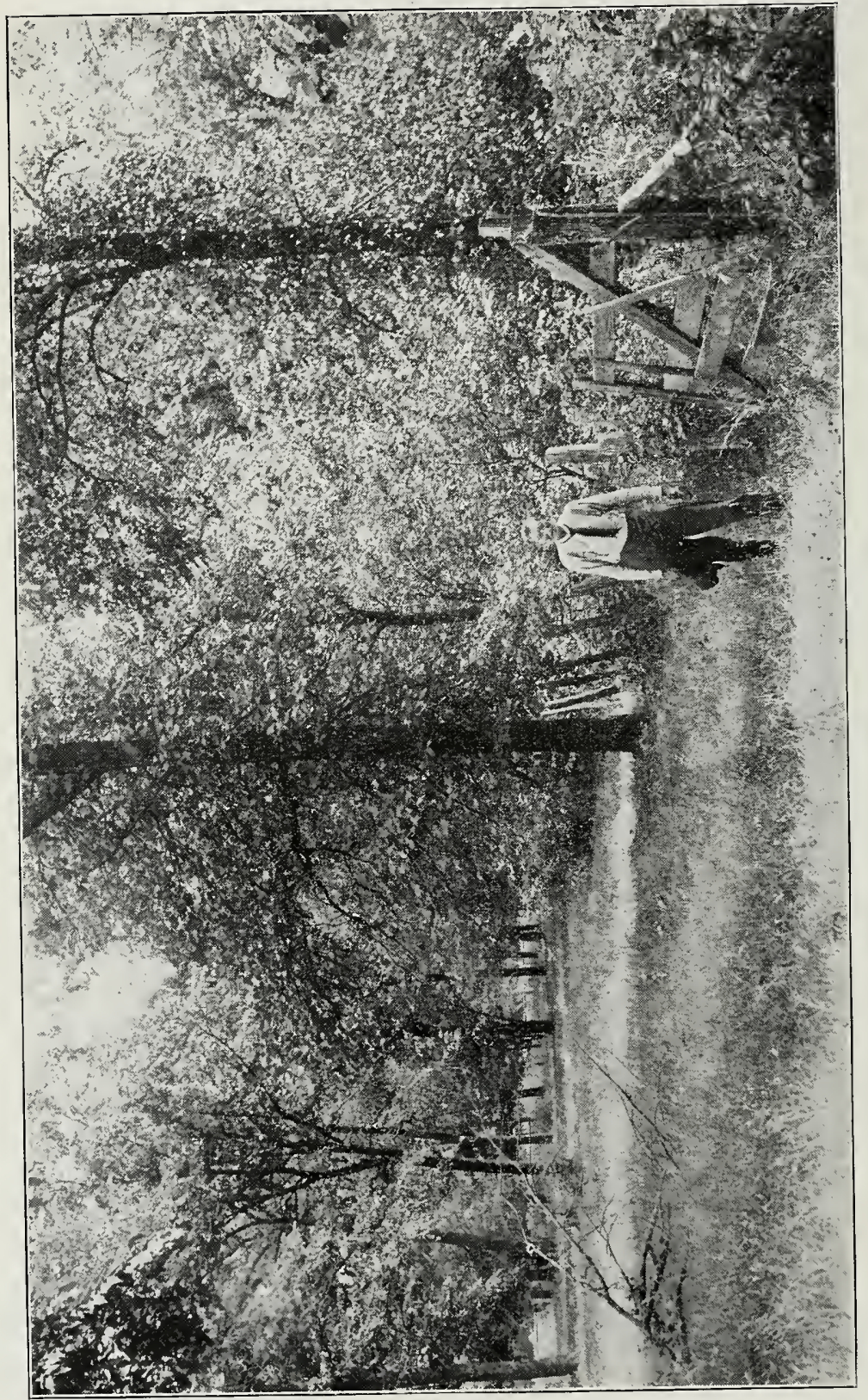

这 


\title{
WOOD AS A CROP IN ILLINOIS
}

\author{
By C. J. TELFORD
}

\section{A Wood Supply for Illinois.}

Illinois, like other states, has a forestry problem, which involves interstate and national relations affecting the interests of every individual owner of forest property and of every user of forest products. No state in the union is a separate and independent unit, completely supplying its own demand for wood and finding within its own borders a profitable market for all that it can produce. Those states are most favorably situated which are most nearly self-sufficient, and those are least so which are farthest removed from their markets and their outside sources of supply. In this respect, our state is unfortunate, for it ranks high as a user of wood but low as a producer. Qnly one-fifth of the wood used annually in the state is grown within its boundaries, and the bulk of the local supply is cordwood. We get annually from other states not only those kinds of high-grade lumber which we cannot produce ourselves in sufficient quantity, but also many millions of dollars worth of posts, railroad ties, piling, mine timbers, veneer logs, and lumber which we could easily grow at home.

In Illinois all users of wood products are faced with rapidly rising prices, because the most important sources of supply are becoming more and more distant as the nearer sources are exhausted, and because the United States as a whole is using up annually four times as much wood as is being grown in the forests of the country. We are, in short, in the early stages of a timber famine that is certain to become more serious except as intelligent remedies are adopted, both nationally and locally. At the same time that we advocate a conservation program for the whole country, we must look to the woodlands of our own state for all possible relief.

\section{Extent of Woodlands and Waste Lands in Illinois.}

Illinois now contains three million acres of forest, with an average stand of 1,158 board feet per acre-all that is left of our original forested area of fifteen million acres with an average stand of 4,280 board feet per acre. The area of our woodlands is still diminishing, at the rate of 4,500 acres a year, and the remaining forest properties are being rapidly impoverished by overcutting-taking out of them year after year more than they are gaining by growth. In fact, less than three-fifths of the annual cut is now being replaced by growth,* and if the present rate of consumption were to

* This is not guesswork, but the result of an extensive study of the rate of growth of various kinds of trees on various soils and in various situations in different parts of the state, as shown in "The Economics of Forestry in the State", the second report on a forest survey of Illinois, by H. H. Chapman and R. B. Miller, Art. III, Vol. XV of the Bulletin of the Natural History Survey. 
be continued with no attempt to make good the deficit, our state would be completely stripped of forest in $3 \mathrm{I}$ years. Moreover, the area of waste lands in the state, which increased 250,000 acres in the decade between 1910 and 1920, now exceeds a million and a half acres.

The present tendency in Illinois is thus aggravating instead of relieving the prevailing conditions, and our remedy is to be found in a reversal of the present downward movement by improving the management and thus increasing the yield of our existing forest tracts and by beginning to grow timber on available waste lands and on other lands better adapted to forest culture than to their present use.

The principal obstacles to this change of direction are an imperfect knowledge of the dangerous character of the present situation, a generally inadequate appreciation of the value of the farm wood-lot as it is and as it might be made under thoroughly intelligent management and a judicious utilization of its products, and a lack of reliable information and educated judgment as to the economic possibilities of forest culture in Illinois on lands not fit for general agriculture but adapted to the growth of valuable trees.

\section{IMPORTANCE OF FARM WOOD-LOTS AS A SOURCE OF SUPPLY}

For the owners of woodlands in Illinois, there is promise of good profit as a result of the national shortage of forest products. Two out of every five farmers in the state have wood-lots, but comparatively few of them yet appreciate the promise of profits from wood as a crop. Although the managers of wood-using industries, becoming aware of the threatening shortage of suitable materials, co-operate as far as they can with local, state, and national movements toward more productive forests, there will be little progress in that direction in Illinois until the farm-owners are so convinced of the benefits to themselves that they will give the same skill and attention to the growing of wood as they give to other crops. The immediate need is not only a reforestation of cut-over lands that are now wild, and a utilization of waste lands that are now bare, but also the maintenance and improvement of the present woodlands. State forests may well be developed, when their advantages become better understood by the public, to such an extent as to supply a considerable part of the local demands for wood; but in the meantime our hope rests mainly with the owners of farm wood-lots which can be made more productive by good management and with the owners of waste lands which can be planted to trees for private profit.

\section{Possibility of Profits from Wood-lots.}

This promise of profits from woods crops should have a positive influence on every farmer's view of his wood-lot. Instead of thinking merely of its protective value-to shelter his buildings, his stock, and his fields against winds, to stop erosion on slopes, and to stabilize local water supplies-he should also think now of the money to be made year after year out of his crop of wood. It is no longer true that the growing of wood as a crop is profitable only where cheap lands, rapid growth rates, and accessible markets make production costs low. As a result of the greatly increased prices which forest products are bringing, the farm wood-lot is becoming more and more profitable in many places in Illinois, as well as in other states. 


\section{Value of the Annual Wood Crop in Illinois.}

The annual wood crop in Illinois is even now of greater value than all the butter produced or all the orchard crops grown in the state.* Our present woodland area of three million acres, if consolidated in a strip extending the whole length of the state from Cairo to the $W$ isconsin line, would be only $12 \mathrm{I} / 3$ miles wide; and yet the annual yield in the form of cordwood, mine timbers, fence posts, lumber, railroad ties, veneer logs, piling, and cooperage stock, totals I 15 million cubic feet and is worth thirteen million dollars. The average yield is thus over four dollars per acre. This is without any systematic practice of wood-lot management, and the yield could easily be doubled by good management, without any planting at all. In addition, we have at least two million acres of land that is too poor to produce any other crop at a profit. Surely the problem of growing wood as a crop, not just letting it grow wild, is worthy of as much attention as we devote to orcharding.

\section{FUNDAMENTALS OF WOODLAND MANAGEMENT}

Successful woodland management is based on the simple principle of giving the forests a fair chance to produce their best. This means a wise selection of trees that are ready to be harvested, careful cutting of them so as to avoid waste, a weeding out of undesirable kinds in order that the smaller trees of valuable kinds may grow to better size, and prevention of injuries by fire and live-stock.

\section{Good Forestry Practice.}

A few farmers in Illinois are already following this principle to some extent. They use spare time in winter to cut fuel wood, fence posts, and a little timber for repairing their buildings; and in years when prices are high they make extra money by intelligent marketing of posts, cross-ties, piling, saw-logs, and other forest products. They keep their woods clean of dead timber, brush piles, and other rubbish, so as to reduce the danger of fire. They never burn over a wood-lot with the unwise aim of improving grazing, and they exclude cattle and other stock that would forage on seedlings and saplings. In short, they do nothing to destroy the value of a forest, and they take some care to maintain it so as to reap a profit through the years. They are, to that extent, "practicing forestry."

Such farmers could often get still higher returns by giving special attention to certain kinds of trees that are best suited to local conditions and that can be marketed to the best advantage, and they can often choose between different kinds of products into which to convert their timber. Intelligent attention to these requirements is sure to repay all their efforts. 


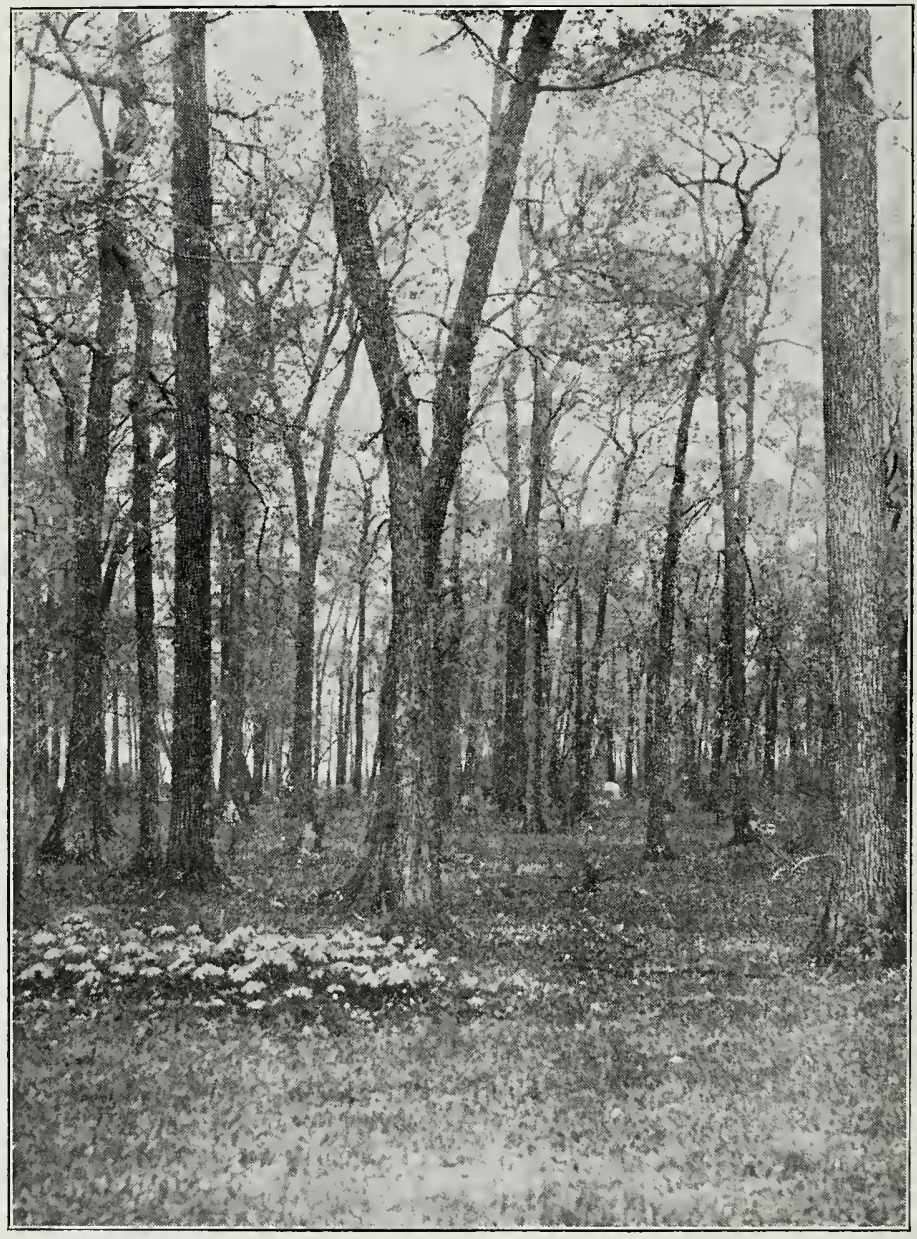

PASTURED WOODLAND. NO REPRODUCTION.

(Cook county.) 


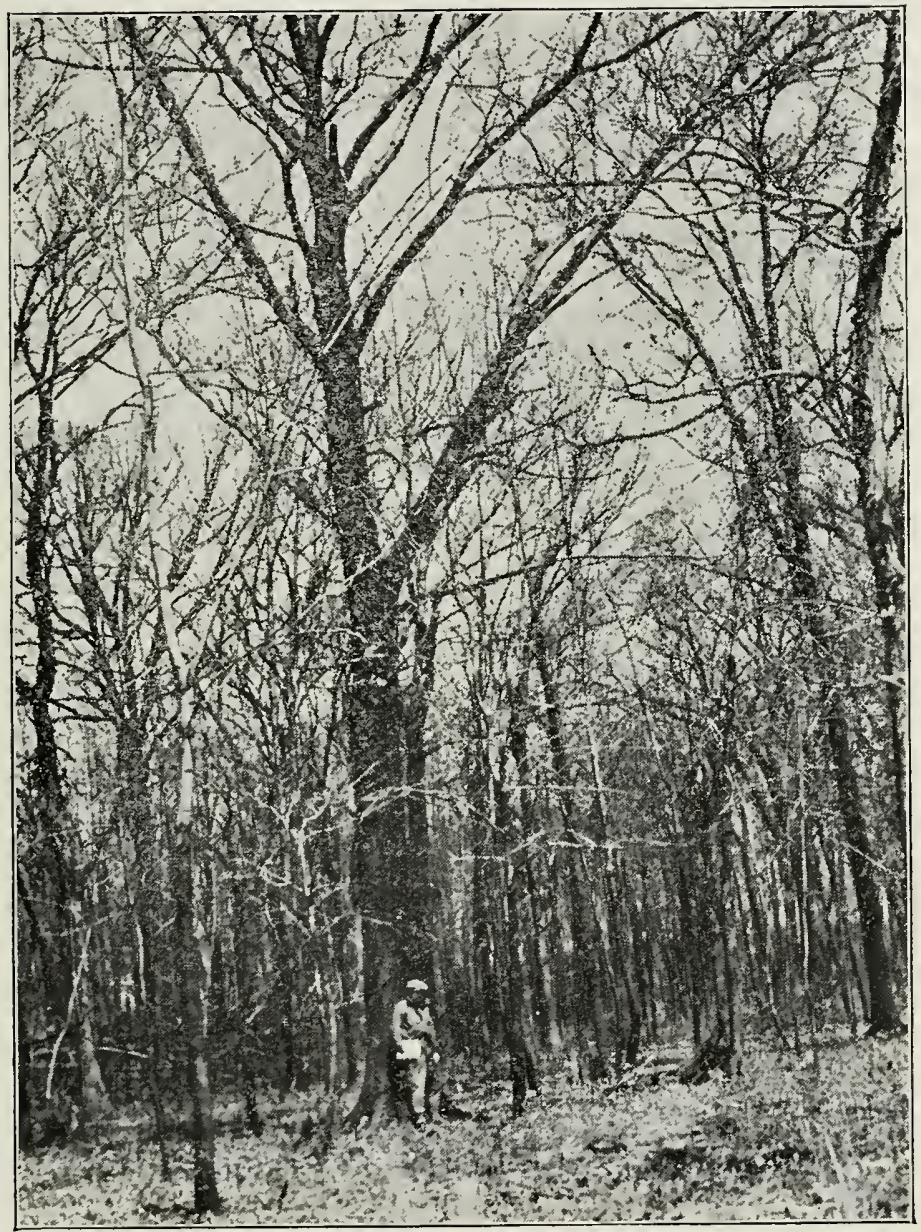

WOODLAND NOT PASTURED. EXCELLENT REPRODUCTION. (McHenry county.) 


\section{Unwise Practices.}

Ignorance and carelessness, on the other hand, are rapidly impoverishing our wooded lands. Over-cutting is only one of several common evils. In addition to the damage caused by fires* that sweep over tracts of relatively continuous forest in the southern and extreme western parts of the state, great injury is being done, especially in central and northern Illinois, because of the mistaken belief that wood-lots are good places for pasturage. A state-wide questionnaire conducted by the Natural History Survey shows that very few farmers now exclude stock from their woodlands. Pasturing is partly due to the desire for shade in hot weather, but this purpose can be just as well served by a few trees fenced off from the rest. The amount of forage which the stock can use to advantage is a far more important item, and it gives an immediate return from wooded areas that are all too often regarded as otherwise profitless; but such forage is generally so inferior to the grasses of an open pasture that it is better economy to keep the animals out of the woods. Woodland pasture provides less forage material per acre, with a larger percentage of weeds; and grasses grown in the woods are less nutritious than in open pasture ${ }^{* *}$. A wood-lot under proper management, on the other hand, in most cases will yield a higher return in wood products year after year than is possible from grazing. Each owner must choose between the two, for he cannot practice both successfully on the same land.

\section{Damages Caused by Fire and Grazing.}

"To make the grass grow better," thousands of acres of woods in Illinois are burnt over again and again. This cannot be too strongly condemned. To appreciate the damage resulting from fire and grazing, we must understand that grasses and trees are conflicting kinds of vegetation in Illinois. A very slight agency is able to upset the balance between them and determine whether a forest or a sod shall hold the contested site. The forest's defences against grass consist in shade and in a leaf mulch completely covering the earth. This leaf mulch also protects the forest floor against excessive evaporation and serves to cultivate and fertilize the ground, for in it live bacteria which are the agents of chemical reactions of the greatest importance. It is obvious that fire destroys this mulch and the small trees as well. It is less obvious but equally true that sunlight also burns up this essential covering. The first effect of grazing is injury to the seedlings and small trees, so that a grazed wood-lot is strikingly free from underbrush. More sunlight then reaches the ground, kills the bacteria in the leaf mulch, and encourages the growth of grasses. The formation of a sod uses up moisture that is needed by the trees. The trampling by the stock makes the ground more compact and less absorbent. No young trees can grow, the old trees gradually die out-and the land is thus finally cleared. Protection against fire and grazing is, therefore, the first requisite of wood-lot management.

* For statistics on the extent of losses from forest fires in the state, and for measures to be taken against these losses, see Forestry Circular No. 2, "Fire Prevention in Illinois", by Robert B. Miller, Forester, State Natural History Survey.

** The inferiority of woodland pasture is shown by Welton and Morris of the State Agr. Exp. Sta. at Wooster, Ohio, in their report on the "Composition of Grass from Woodland and from Open Pasture", published in the Jour. Amer. Soc. Agron., V. 18, No. 3, March, 1926; (1) "Woodland pasture yielded $85 \%$ less dry matter than that grown in the open", (2) "Woodland pasture contained $32 \%$ more weeds," (3) "Woodland pasture pound for pound of actual bluegrass, contained $22 \%$ less total nutrients." 


\section{KINDS OF SOILS SUITABLE FOR WOOD CROPS}

Some soils, of course, are better than others for growing wood-a fact due to differences in their physical structure and chemical composition. Hardpan soils and sands are least productive, because the former are too compact and the latter too porous. Upland loams, bottomland heavy loams, and bottomland light loams are better adapted to trees, in the order named. The following table shows the approximate ratio of productiveness for unmanaged tree-growth characteristic of each soil:

\begin{tabular}{|c|c|}
\hline Kind of Soil & $\begin{array}{c}\text { Ratio of } \\
\text { Productiveness }\end{array}$ \\
\hline Hardpan soils .. & I \\
\hline Sands $\ldots \ldots \ldots \ldots \ldots \ldots \ldots \ldots \ldots \ldots \ldots$ & I.8 \\
\hline Upland loams $\ldots \ldots \ldots \ldots \ldots \ldots \ldots \ldots$ & 2.3 \\
\hline Bottomland heavy loams............... & 2.8 \\
\hline Bottomland light loams................ & 6.3 \\
\hline
\end{tabular}

The hardpan soils, which are very compact, light-colored, sour soils underlain with a layer of silty clay, include some 386,000 acres now forested in Illinois. They are known locally as post oak flats. Besides oak, practically the only hardwoods native to them are hickories. The growth rates are so slow and the quality of wood is so low that the net value of the annual crop hardly pays the taxes. There is no known way of producing wood crops profitably on these soils, as no introduced species have proved able to grow well under such adverse conditions.

\section{Profitable Plantations on Sands.}

The sands cover a total area of 300,000 acres in the state, of which 9I,000 acres are forested. Here too, oaks and hickories (in the proportion of 9 to $\mathrm{I}$ ) are virtually the only native hardwoods. Since a vegetative cover is essential to prevent the sands from shifting about and burying adjoining fields, crops, and even buildings, many landowners have encouraged native forests and have planted bare areas to trees as an insurance against sand drift. Profit as well as protection can be secured from certain pines which grow well on these sands. A yearly average of 545 board feet of white pine with a stumpage value of $\$ 6.50$ per acre, or a total stumpage value of $\$ 325$ over a period of 50 years, has been grown on Illinois dune sand. The actual cash expenditure for planting stock and taxes should not exceed \$40 per acre, leaving a net yearly return of more than $\$ 5.50$ per acre if interest on the cash outlay is not considered. More profitable forestry is possible on sands when introduced species are grown systematically in plantations.

\section{Good Annual Yields from Loams.}

There are in Illinois 2,522,000 acres of loams capable of producing a sustained net revenue from the trees naturally growing on them now. How large this net revenue can be annually, depends on several varying factors:

( I) The rate of growth of different kinds of trees under different conditions of soil fertility and moisture.

(2) The per cent of this growth that can be utilized.

(3) The cost of cutting and manufacturing the products.

(4) The cost of transportation to markets.

(5) The sale value of the various wood products. 


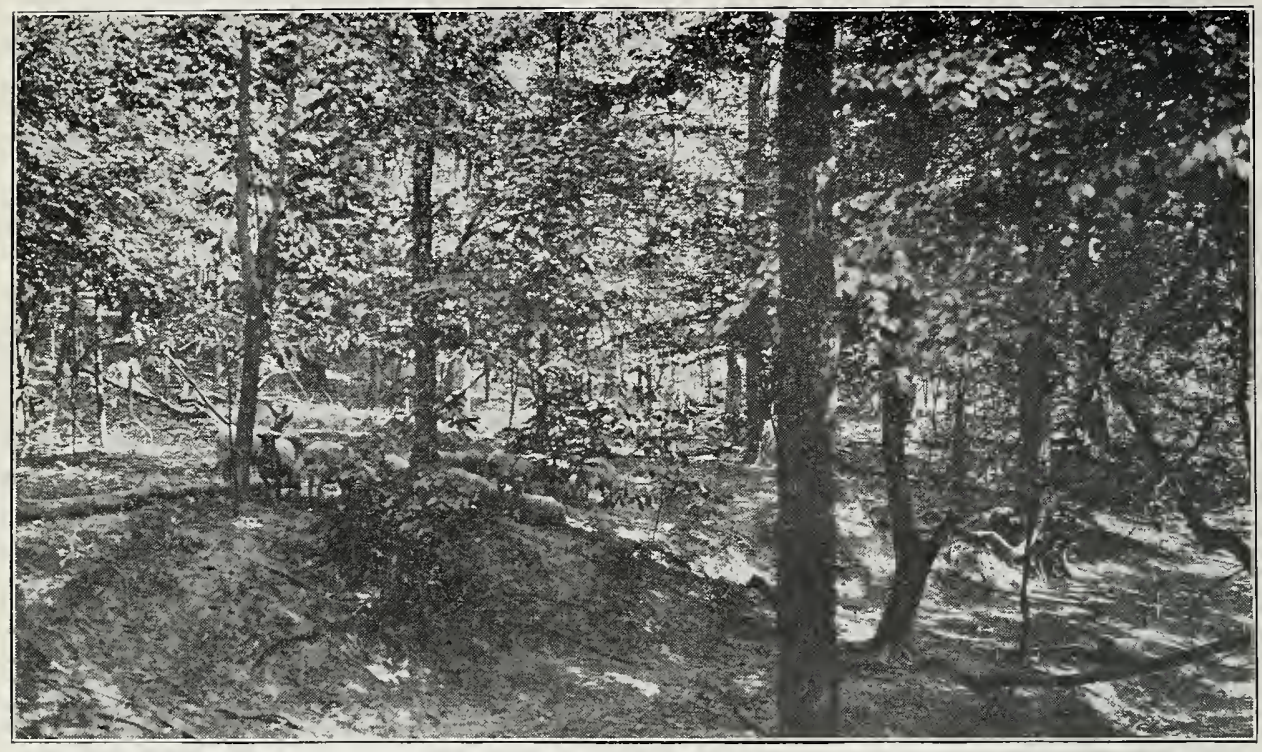

WOOD-LOT GRAZED BY SHEEP AND HOGS.

Some reproduction $\mathrm{I}_{5}$ years o!d, previous to grazing. (Gallatin county.)

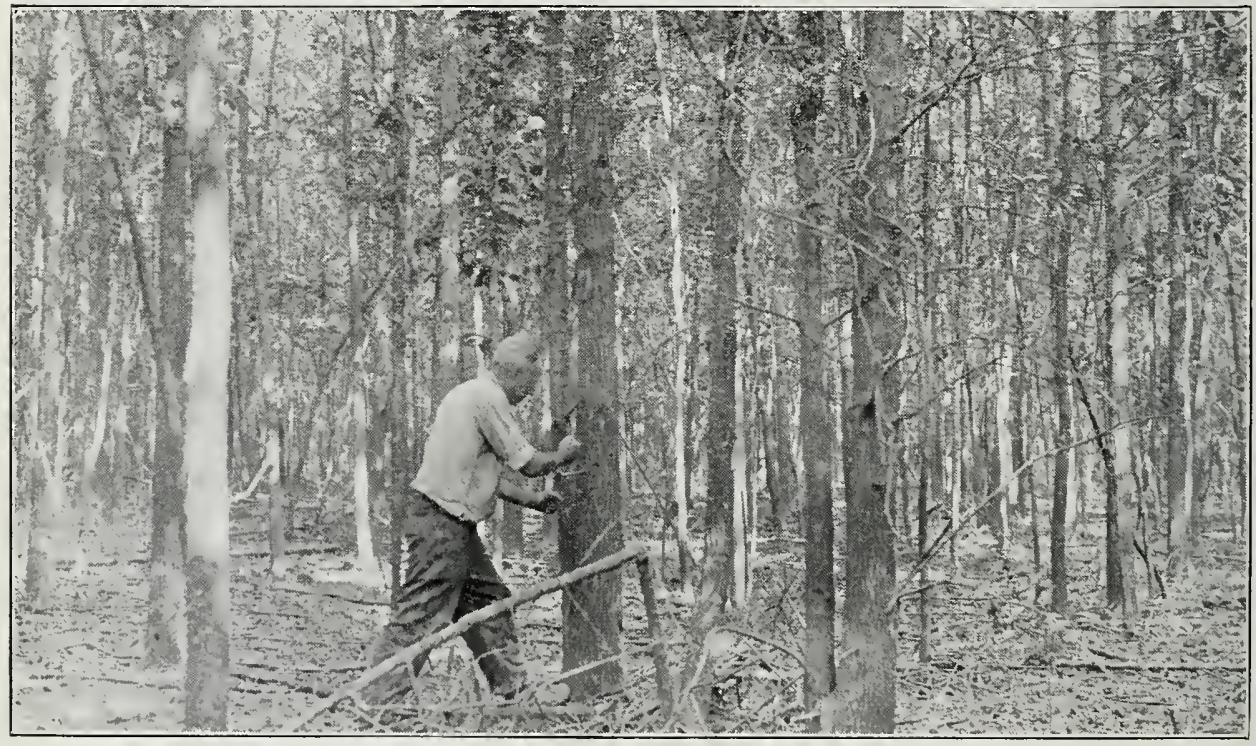

FULLY STOCKED IIARDWOOD, 25 IEARS OLD, SELF-SEEDED.

On land that had proved too wet for cultivation. (Wabash bottoms.)

Ash, pin oak, swamp white oak, sweet gum, and honey locust. 
The first three of these factors are generally uniform in all parts of the state, but transportation costs and sale values vary widely because markets for all forms of products are not everywhere equally accessible. Although the profitable management of each wcod-lot therefore becomes a separate problem, yet it is possible, considering all these factors on a basis of state-wide average conditions, to arrange the most common products in the following order, from most profitable to least profitable: ( 1 ) high-grade veneer logs, (2) posts, (3) piling, (4) ties, (5) lumber, (6) mine timber, (7) cooperage stock, (8) average veneer logs, and (9) cordwood. The average net returns from wood-lots yielding high-grade veneer logs, posts, and piling are roughly twice as great as from those yielding ties, lumber, mine timber, cooperage, and average veneer logs, and ten times as great as from those yielding only cordwood. These and other data on use and production of wood on farms are based partly on the results of a questionnaire sent to $\mathrm{I}, 600$ farmers through co-operation with the Office of Farm Organization and Management and the State Leader of Farm Advisers.*

\section{PROFITS FROM TYPICAL WOOD-LOT CROPS}

\section{Railroad Ties.}

The production of railroad ties offers the fairest index of returns because the degree of utilization, the cost of manufacture, and sale prices are uniform throughout the state, because ties can readily be made by the wood-lot owner without expensive equipment, and because a market exists along practically every railroad right-of-way. On upland loams fully-stocked hardwood stands show net annual returns in the form of ties as high as $\$ 2.50$ per acre with an average of $\$ 1.25$, and if the tops are utilized for mine timbers, the net stumpage value averages $\$ 1.60$ annually. These returns require only that the forests be kept fully stocked with such trees as are now growing in them, and by this single step the total amount grown annually in the state will be increased 54 per cent, nearly counterbalancing the present drain. These returns can be doubled by simple forms of good management and by a better utilization of the growth. On the bottomlands, where growth rates are higher, these returns can well be trebled.

Practically every kind of tree not otherwise more valuable is suitable for the manufacture of cross-ties. In addition to heart-wood ties of white oak, chestnut and other hardwoods, which naturally resist wear and decay, railroads are buying increasing numbers of sapwood ties of these and other species and making them resistant by preservative treatment. Some of the important species thus marketable are: the red and black oaks; ashes and hickories; honey locust and beech; birches, cherries, and gums; hard and soft maples; elms, hackberry, sycamore, and butternut. The great demand for ties (about five million are needed annually for the railroads in Illinois) is a striking proof of the fact that timber crops of all these species will find a ready market.

* Each county agent was asked to supply the names of representative farmers in his county who owned woodland. Another list of names of farmers having over 40 acres of woodland was secured through the assistance of Mr. A. J. Surratt, Agricultural Statistician at Springfield. The Natural History Survey takes this occasion to thank the farmers who aided the investigation by furnishing data. 


\section{Logs.}

Probably one-third of the wood-lots in the state still contain considerable sawtimber. The average amount cut for lumber each year, as shown by the returns from the questionnaire, is about one-sixth of the total wood cut. Half of the saw-timber is used by farmers themselves, and the other half is sold at stumpage prices ranging from $\$ 3$ per thousand board feet for sycamore up to $\$ 85$ per thousand for walnut. Veneer logs of white oak, for example, command prices up to or even more than $\$ 25$ on the stump, while poorer grades of oak lumber are sometimes sold for less than half this figure. When the lumber is cut by the owner and sawed in a customs mill, higher net profits are realized.

\section{Mine Timber.}

The coal mines in Illinois require large quantities of small timbers in the round, pieces down to 4 or 5 inches in diameter of nearly all species being suitable for this purpose. The prices paid in I92I at the mines for the larger sizes, in the form of legs and bars, averaged 26.7 cents per cubic foot, and for the smaller sizes (props) r6.2 cents. Reduced to cords, by the equivalent of 80 cubic feet per cord, these prices give \$21.36 per cord for legs and bars, and \$12.96 for props. Two-thirds of the present supply is obtained within the state; and, rather than be forced to pay excessive freight on these low-grade materials, the mines will always offer an active market for locally grown timber. As the cost of cutting and hauling to the railroad is apt to be similar for similar conditions throughout the state, whatever is saved in freight will increase the profit to the contractor who purchases the timber or increase the stumpage value to the owner himself.

\section{Piling.}

The stumpage value of timber suitable for piling averages $\$ 3.15$ per pile (average contents 22 cubic feet). Sale prices, of course, vary greatly in different parts of the state, depending upon distances from markets. Species most in demand for piling include oaks, gums, sycamore, and ash. In Hamilton County, for example, on waste bottomland selling for $\$ 20$ per acre, a yield of 80 piles, or 3200 linear feet, in a $40-$ year period is possible in well managed stands of pin oak. If the cost of management is met by thinnings before the final crop is harvested, this yield represents a net return of $\$ 130$, which, discounted at 4 per cent for 40 years, gives the land a value of $\$ 34$ per acre.

\section{Posts.}

At present prices and costs, fence posts are the most profitable wood crop that can be grown in Illinois. They command a price nearly equal to that of the highest quality of lumber, when comparison is based on cubic contents of the tree required to yield each product respectively. But while it requires Ioo years or more to grow logs suitable for high-priced veneers, and 50 to 70 years for good piling, posts can be grown in from 15 to 25 years, depending on the soil.

Two hundred million posts are now in use in the 625,000 miles of fences on farms in Illinois-enough fencing to encircle the whole earth 25 times. One-tenth of this number, or about twenty million posts a year, will be needed to keep up the farm fencing throughout the state. Answers to questionnaires sent out to farmers indicate that, 
in spite of depletion, the woodlands of the state are still supplying about half of the fence posts needed annually on farms, or a total of ten million posts; but a shortage has already developed and will probably increase in severity. By adopting preservative treatment of posts, the farmers of Illinois can produce, at the present rate, enough to supply all of their needs for fencing.

In the southern part of the state white oak posts sell at the lumber yards for I 6 cents, and red cedar and sassafras at 30 to to cents. Mulberry posts have been sold in Union county for 7 cents each in the woods, but this species is generally reserved by farmers when selling timber for mine props. In northern Illinois white cedar posts from Wisconsin sell at 25 to 45 cents, red cedar at 45 cents, and creosoted long-leaf pine at 50 cents. Native white or burr oak pasts could be bought in the summer of 1922 in northern Illinois for 15 cents, and Osage orange and black locust for to cents each.

\section{Cordwood.}

Over half the wood now being cut in Illinois is used for fuel. The largest consumers are farmers who own wood-lots and cut their own wood. A certain amount is sold to city and town dwellers and to farmers who do not own woodland, but this quantity is limited by the comparatively high cost of transportation and the greater labor required in cutting and splitting, storing, and piling the wood for use as compared with coal, and also by the necessity of seasoning green wood.

From the returns of our questionnaire we find that farmers consume 93 per cent of all fuelwood used in the state, and that the average yield per acre annually is onethird of a cord. It was found that the average farm of $\mathrm{I} 4 \mathrm{O}$ acres which burned wood exclusively used 21.+ cords per year, while on farms which burned both coal and wood I 3.4 cords were used and 7.66 tons of coal. When the area of woodland per farm is more than 5 acres all the owners make considerable use of wood for fuel, but when the wood-lot is less than 5 acres per farm, only half of such owners burn wood for fuel.* These small wood-lots are often grazed and park-like, or are prized for shelter or appearance, and are not adequate as a source of wood fuel.

Considering the fact that labor by the farmer, his family, or hired help is, in nearly all cases, expended in place of money, the cash outlay of those who burn both roal and wood is probably less than for coal-burners, while those burning wood exclusively expend considerably less cash. The cutting of cordwood in winter months by men who would otherwise be laid off, helps to solve the problem of steady employment, and still further increases the advantage of the use of wood for fuel.

The drawbacks to this use of wood lie in the amount of labor required for its handling, and in regions where labor is scarce coal may be used for this reason. Wood, being more bulky than coal, will not stand transportation by either wagon or railroad over long distances in competition with coal; hence, for any but local consumption on short hauls, wood loses the economic advantage which it bids fair always to retain for home use on farms.

* A cord of black locust or hickory is the equivalent of a ton of coal. A cord of oak is approximately equivalent to .9 tons of coal; beech, walnut and ash to . 8 ton; red maple, gum, sycamore, and elm to .7 ton; yellow poplar and cottonwood to .6 ton; willow and basswood to .5 ton. The average cost of coal to farmers is $\$ 6.00$ per ton. For wood the cost of stumpage plus labor cost is $\$ 2.94$ per cord, or the equivalent of $\$ 3.671 / 2$ per ton of coal, a saving of 45 per cent over coal prices. This indicates that wood obtained from the woodiot or neighbors at $\$ 2.94$ a cord gives 79.6 per cent greater fuel-value for species with .8 tons fuel value per cord than coal at $\$ 6.60$ per ton. 


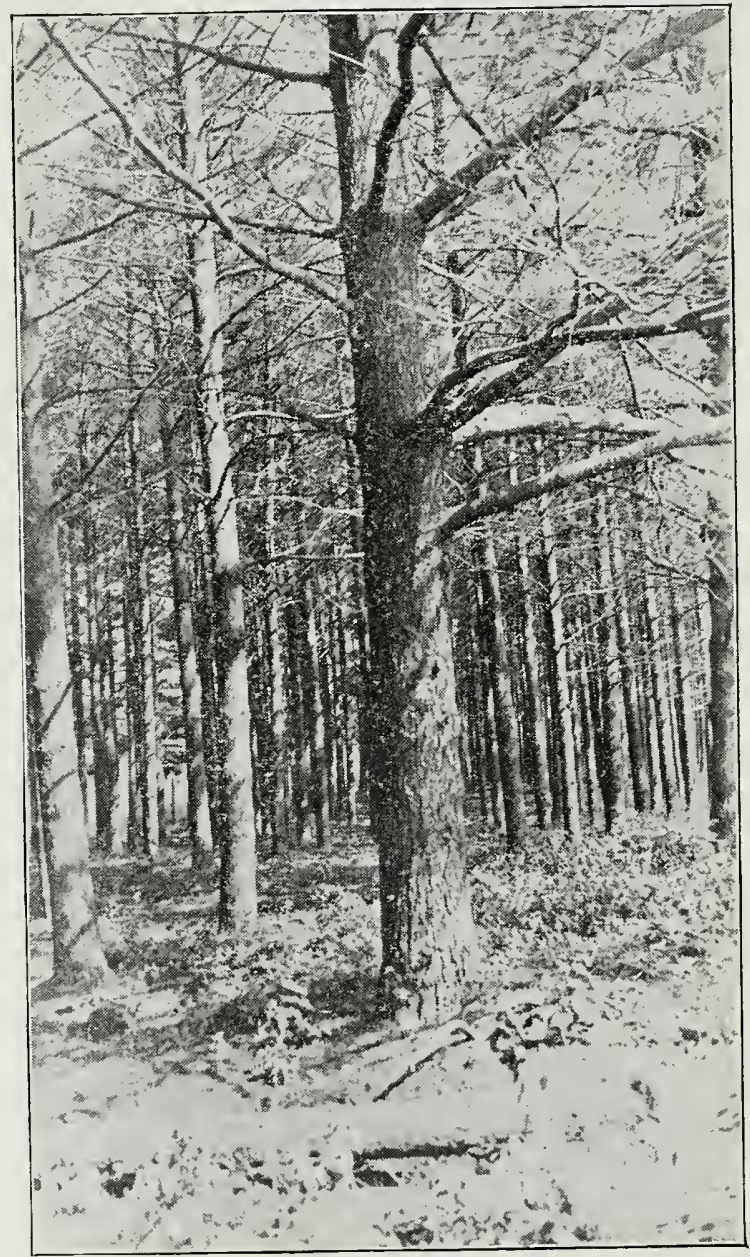

WHITE PINE PLANTATION.

Fifty years old, 27,00o board feet to the acre. (Grundy county.) 


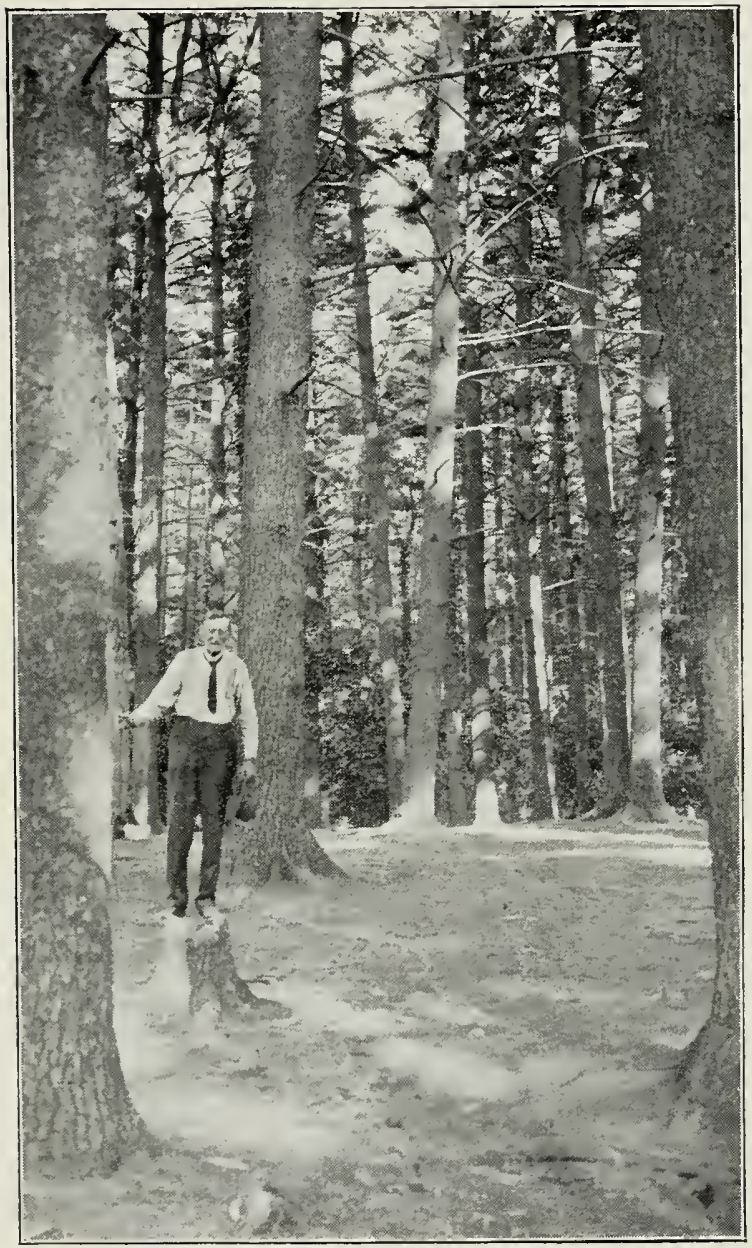

WHITE PINE PLANTATION.

Seventy-five years old, 40,000 board feet to the acre. (Ogle county.) 


\section{PROFITS FROM PLANTATIONS}

Trees may do well where other crops fail. On many farms some of the land yields but a small profit or none at all when planted to grain. It is poor economy to continue to cultivate such land or to let it lie idle and not even pay its own taxes. Every acre should be put to the use for which it is best suited, for the key to successful farming today is the careful classification of land and careful selection of crops that will bring the greatest net returns in the long run.

Forestry affords a good use for idle, waste, and low-grade lands. The area of waste lands in Illinois increased a quarter of a million acres in the decade rgro to 1920 , and in the latter year it amounted to $1,577,663$ acres, or 5 per cent of the entire farm area. Most of the land which is unsuited to agriculture is well adapted to the production of timber of fair or even superior quality, such as is most needed by our wood-using industries. Replanting these wastes offers in most cases the best and frequently the only means of restoring them to profitable use. Taxes are usually the same whether these lands are left bare or planted to forest, and any returns above planting costs are net gains to the owner. For example, as previously stated, a timber crop worth $\$ 325$ an acre on the stump has been raised in 50 years on Illinois dune sand. Many of the idle waste lands are capable of growing during this interval pine crops having a stumpage value of at least $\$ 400$ an acre, or twice this figure if the owner saws the logs himself. A return averaging $\$ 8.00$ a year an acre from otherwise unproductive land is thus possible to the owner who is in position to carry the initial outlay invested in planting costs over the interval required to mature the crop. These planting costs may be made very low (less than $\$ 15$ per acre) if state-owned nurseries are established to furnish planting-stock.

Plantations of black walnut on soil of good agricultural quality will yield up to Ioo cubic feet, or 3,000 pounds, of wood per year, giving over 300 board feet per year on an acre. Average prices for walnut logs of good quality, on the stump, are about $\$ 50$ per thousand board feet.

From a plantation in Edgar County containing 20 r trees per acre there were 85 trees which had attained a merchantable size after 50 years, and from them a yield of I I, 525 B. F. valued at $\$ 576.25$ was secured. After deduction of a planting cost of $\$ 15.00$ per acre carried at $4 \%$ compound interest there is still left $\$ 469.65$ to cover taxes and returns for the use of the land. Properly discounted, this sum is an average return of $\$ 3.08$ per acre annually, and the II 6 trees left on the acre furnish shelter for the stock and promise another substantial cut of walnut. This indicates that a walnut plantation, in addition to serving its primary purpose as a grove and shelter, will also yield a crop of reasonably high value. Hardwood plantations on fertile sites made for the purpose of producing logs should contain walnut, at least in part, on account of its relatively high stumpage value. This high value should be maintained or even increased in the future since this species has superior qualities for the manufacture of gun stocks, furniture and aeroplane propellers. 


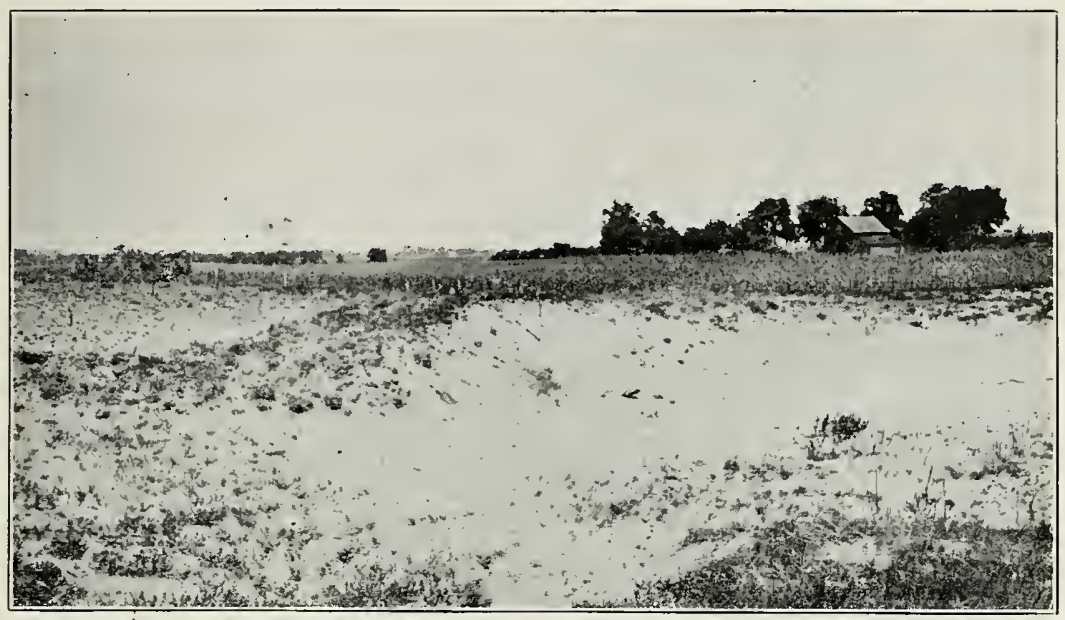

WASTE LAND.

Dune sand. (Mason county.) Illinois has 300,000 acres of sand.

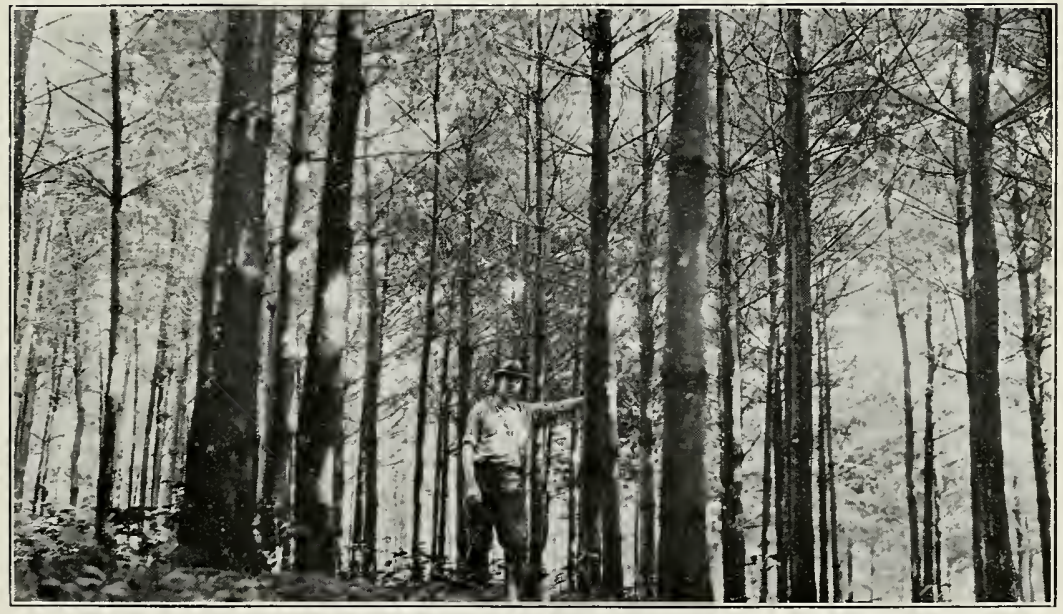

THE CROP.

Twenty-year old white pine on dune sand.

(Ogle county.) 


\section{Answering Possible Objections to the Growing of Wood as a Crop.}

The chief objections urged against actually undertaking to grow timber as a crop are based, not so much on the prices of wood products or on the yields per acre which are possible, as on the crop-period. The long time required, which for private enterprise is often regarded as prohibitive, results in an accumulation of interest deemed necessary to return a reasonable per cent on the investment, and of taxes at compound interest.

For farmers who own wood-lots there are several strong arguments offsetting these objections. In the first place, the wood-lot, unless already badly cut-over or nearly ruined by grazing, can usually bring an annual profit, even if it does not approach the full possible yield of the land in wood crops. The wood-lot is a going business and, if managed as such, incurs no compound interest charges; each year's expense is met by income from cuttings. This is the proper condition to maintain, and it is exemplified by many wood-lots in southern Illinois which continue to yield good quantities of high-grade lumber, posts, and other products, year after year.

In the second place, it is not necessary to wait 30 to 80 years for yields from a wood-lot. Even when plantations are made on bare soil, the intensive use to which a farmer can put the small material enables him by thinnings to obtain fuel, stakes, fence posts, and other small-sized material in not over 15 years, and often even within 8 to Io years; and these returns will often pay the taxes and carry the investment until the more valuable product is ready for cutting.

Finally, with some encouragement from the state, owners of waste lands can afford to plant trees on a large scale with as much assurance of returns from their investments as is usually enjoyed in agricultural or industrial undertakings. Other states-New York, Pennsylvania, and Ohio, for example-have already established

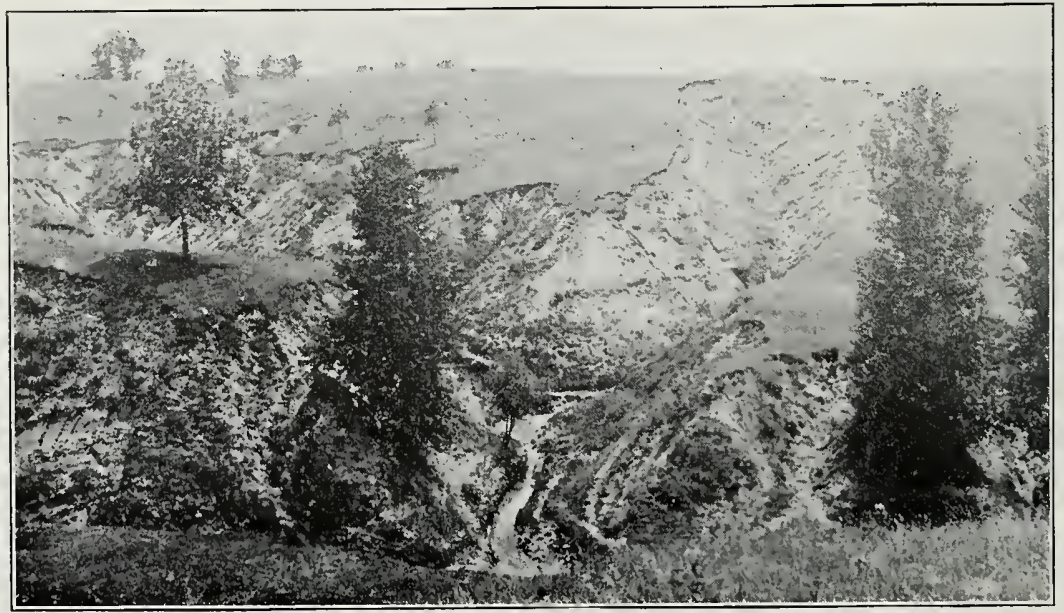

WASTE LAND.

Eroded upland.

(Carroll county.)

Illinois has $1,577,663$ acres of waste land now, and allows 25,000 acres more to become waste every year. 
various agencies to encourage reforestation of cut-over lands and barren wastes. 'The time has come for Illinois to formulate a definite policy as a basis for legislative action that will insure the success of similar enterprises by land-owners in this state.

\section{A FOREST POLICY FOR THE STATE}

It is out of the question for Illinois to curtail the production of farm crops, livestock, and horticultural products for the sake of growing forests on soils better adapted to these higher uses. But it should be our policy, at the same time that we protect and develop the present forests, to undertake the growing of wood on soils unprofitable for food crops, so that we may produce as large a percentage as possible of home-grown timber, and to take a lively interest in forest production in neighboring states and in the country at large.

The greatest immediate need is for a thorough educational program. 'The public must be informed on measures required to protect our present forests and develop them to their fullest possible capacity, and to reforest as much of our $1,577,663$ acres of wastelands as is economically justifiable. Wood-culture should be taught in our public schools and colleges, and especially in the State University.

To provide material for this educational work, there is need of investigations of problems concerning wood crops, in addition to those already made by the Natural History Survey. Rates of growth of various kinds of trees under various conditions of soil fertility and moisture, and methods of marketing wood produced in various parts of the state, are subjects especially deserving of much more detailed study.

To organize these investigations and direct them to advantage, as well as to carry on the necessary educational work among landowners and in schools, a forestry division contemplated by the State law of 1924 should be established at the University of Illinois, and for this it is only necessary that a definite appropriation should be made to the University "for forestry investigational purposes".*

Other important features of a general forestry policy calling for immediate attention include the following:

( I) Aid to landowners in protecting large forest areas against fire.

(2) Establishment of a state-owned nursery to supply planting-stock at lower cost than is otherwise possible.

(3) Purchase of tracts to be developed as state forests.

(4) Setting aside of certain areas for experimentation and demonstration.

The policy here outlined is based upon the results of more than five years work by members of the staff of the State Natural History Survey. These results are reported in full in the following publications:

First Report on a Forestry Survey of Illinois:

(Limited to tracts of continuous woodland from Chester, in Randolpl County, to Thebes, in Alexander County)

by Robert B. Miller, March, 1926.

Second Report on a Forest Survey of Illinois: The Economics of Forestry in the State,

by Herman H. Chapman and Robert B. Miller, August, 1924.

Third Report on a Forest Survey of Illinois:

(An inventory of the forests of the state, showing their area and condition and the productiveness of common soil types in terms of forest crops)

by Clarence J. Telford, March, 1926.

Fourth Report on a Forest Survey of Illinois, Iranagement of the Illinois Wood-lot,

by Clarence J. Telford, (in preparation).

* See Laws of Illinois, 53d General Assembly, p. 411. 


\section{SERVICES OFFERED BY THE STATE FOREST SERVICE.}

The Natural History Survey, as a branch of the State Government, is prepared to help farmers and other woodland owners in the following ways:

( I) Instruction through correspondence, or by personal visit if necessary, in proper methods of thinning and developing natural woodlands to their highest productive capacity.

(2) Advice as to cutting trees to the best advantage for various purposes.

(3) Information on means of marketing wood products from any point in the state to such users as furniture factories, veneer plants, railroads, mines, car shops, pulpwood factories, companies using piling, dealers in cordwood, and others.

(4) Estimation of costs of manufacturing various wood products and costs of transportation to various markets.

(5) Identification of tree diseases and insect enemies, when specimens are sent to the Natural History Survey, and advice on methods of eradicating pests.

(6) Advice through correspondence, or by personal visit if necessary to those who desire to plant waste lands, as to the proper species of trees suited to the soils and to the special purposes of the plantations.

(7) Suggestions for solving problems in the protection of woodlands against fire.

(8) Co-operation with other state agencies in all matters related to forestry.

In this connection, the Natural History Survey also pursues the following aims :

(a) To take account of the value of woodlands, existing or proposed, for recreational uses, not only by the inhabitants of the larger cities of the state, but also by the country people and the inhabitants of the smaller towns, whose home surroundings are often oppressively monotonous.

(b) To consider the uses of forests as preserves of the primitive life of the state, of great interest and value to the student of science and his teacher and to the lovers of wild life.

(c) To co-ordinate the forest policy of the state with the movement for the establishment of a system of state parks.

Address inquiries to: Forester,

State Natural History Survey,

Urbana, Illinois. 






UNIVERSITY OF ILLINOIS-URBANA

570IL6C

CIRCULAR

C006

$1-24$

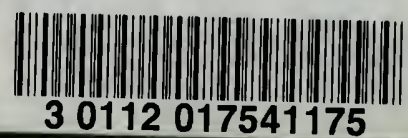

